Research Article

\title{
Prevalence and Predominant Genotype of Hepatitis C Virus Infection and Associated Risk Factors among Pregnant Women in Iran
}

\author{
Fatemeh Farshadpour $\left(\mathbb{D},{ }^{1,2}\right.$ Reza Taherkhani $\mathbb{D}^{1,},{ }^{1,2}$ and Farkhondeh Bakhtiari ${ }^{1}{ }^{1}$ \\ ${ }^{1}$ Department of Virology, School of Medicine, Bushehr University of Medical Sciences, Bushehr, Iran \\ ${ }^{2}$ Persian Gulf Biomedical Sciences Research Institute, Bushehr University of Medical Sciences, Bushehr, Iran \\ Correspondence should be addressed to Reza Taherkhani; taherkhanireza2005@yahoo.com
}

Received 16 May 2021; Revised 2 August 2021; Accepted 24 August 2021; Published 20 September 2021

Academic Editor: Haruki Komatsu

Copyright (C) 2021 Fatemeh Farshadpour et al. This is an open access article distributed under the Creative Commons Attribution License, which permits unrestricted use, distribution, and reproduction in any medium, provided the original work is properly cited.

\begin{abstract}
Objective. Knowledge regarding the prevalence and risk factors of hepatitis C virus (HCV) infection among pregnant women can give clue to health care providers regarding the appropriate management of HCV infection. Therefore, this study was conducted to determine the prevalence, genotypic pattern, and risk factors of HCV infection among pregnant women in the northern shores of the Persian Gulf, south of Iran. Methods. From January 2018 to June 2019, serum samples were obtained from 1425 pregnant women, ages ranging from 14 to 46 years $(28.1 \pm 5.99)$. Serum samples were tested for detection of anti-HCV antibodies using an enzyme-linked immunosorbent assay (ELISA) (HCV Ab ELISA kit, Dia.Pro, Milan, Italy). Following the extraction of nucleic acid, the molecular evaluation of HCV infection was performed by seminested reverse transcriptase-polymerase chain reaction assay (RT-PCR), targeting the $5^{\prime}$ untranslated region $\left(5^{\prime} \mathrm{UTR}\right)$ and core of HCV genome and sequencing. Results. Of the 1425 pregnant women, 19 women $(1.33 \%$, 95\% CI: $0.85 \%-2.07 \%)$ were positive for anti-HCV antibodies. The majority of HCVseropositive women were in the third trimester of pregnancy, educated, and had a history of blood transfusion, abortion, surgery, or dentistry. Moreover, Arab and Fars pregnant women and those aged $>39$ years had the highest rate of HCV seroprevalence. Nevertheless, none of these variables were significantly associated with HCV seropositivity. In contrast, HCV seropositivity was associated with place of residency, so that residents of Khormuj city had significantly higher HCV seroprevalence compared to the residents of other cities (OR: 7.05; 95\% CI: $1.75-28.39 ; P=0.006$ ). According to the molecular evaluation, 9 of the $19 \mathrm{HCV}$-seropositive pregnant women $(47.37 \%)$ had HCV viremia with genotype 3a. Conclusion. This study reports the HCV prevalence of $1.33 \%$ for anti-HCV antibodies and $0.63 \%$ for HCV RNA among pregnant women in the south of Iran. Considering the asymptomatic nature of chronic HCV infection and the fact that vertical transmission is possible in women with detectable viremia, therefore, screening of women before pregnancy is recommended to reduce the risk of HCV infection and its complications during pregnancy.
\end{abstract}

\section{Introduction}

Hepatitis C virus (HCV), a member of the family Flaviviridae, is one of the major causes of chronic liver disease. This positive-stranded RNA virus is predominantly transmitted through exposure to infected blood. The clinical manifestations of HCV infection vary from asymptomatic to acute self-limited or chronic infection, which might progress to cir- rhosis and hepatocellular carcinoma within several years [1-4].

The global prevalence of HCV infection in children varies from $0.05 \%$ to $0.36 \%$ in developed countries and from $1.8 \%$ to $5 \%$ in developing countries [5]. After screening blood donors for hepatitis $\mathrm{C}$, mother-to-child transmission has become the major cause of pediatric HCV infection [6]. There is a direct relationship between maternal viral 
load and vertical transmission of HCV. High maternal viral load increases the risk of infection in the offspring $[5,7]$. If HCV RNA is present in the mother's blood, the rate of vertical transmission is about $4.3 \%[6,8]$. Moreover, in HIVinfected mothers, the rate of vertical transmission increases to $10.8 \%[9,10]$. Although the high maternal viral load is an important factor for the perinatal transmission of $\mathrm{HCV}$, this risk factor is not preventable, as no anti-HCV treatment can currently be prescribed to pregnant women to prevent HCV from replicating [7]. Caution is essential in adopting delivery methods, amniocentesis, or internal fetal monitoring that can increase the fetus' exposure to HCV through infected maternal blood $[5,7]$.

Vertical transmission is almost always limited to women with detectable HCV viremia [11-13]. HCV prevalence in pregnant women is, to some extent, reflective of the prevalence in general population. Therefore, the rate of maternal-fetal transmission of HCV varies in different geographical regions. Universal HCV screening during pregnancy is recommended to provide the best pregnancy management interventions to reduce the risk of perinatal HCV transmission $[10,14]$. The prevalence of HCV in Iran ranges from $0.5 \%$ (95\% CI: $0.4-0.6 \%$ ) in blood donors to $0.6 \%$ (95\% CI: $0.4 \%$ to $0.8 \%$ ) in the general population [ 15 , 16]. However, despite the importance of HCV infection during pregnancy, the epidemiology of $\mathrm{HCV}$ infection among pregnant women remains unknown in most parts of Iran. Therefore, this study is aimed at determining the risk factors, prevalence, and genotypic pattern of hepatitis $\mathrm{C}$ among pregnant women residents in the northern shores of the Persian Gulf, south of Iran. This is the first report on the molecular identification of $\mathrm{HCV}$ infection among pregnant women in the south of Iran.

\section{Material and Methods}

2.1. Study Setting and Population. From January 2018 to June 2019, serum samples were obtained from 1425 pregnant women attending the public health centers for periodical checkups using the multistage cluster sampling method. In this method, five cities of the northern shores of the Persian Gulf, including Bushehr (with an overall population of 253024), Borazjan (230685), Jam (52990), Khormuj (80616), and Ahram (73637), and three of the most populated public health centers from each city located in Southern Iran were selected randomly. After describing the aim of the study, the pregnant women attending these public health centers were requested to participate in this study. During the study period, 1858 pregnant women referred to these public health centers; 1425 of whom agreed to participate in this survey. All pregnant women who agreed to participate and gave written informed consent to use their samples for HCV detection and their data for analysis were included consecutively in this study. The sociodemographic characteristics and pregnancy information were obtained from the participants during enrollment by interviewing using a questionnaire or the records of pregnant women at the public health centers. This study was funded by the Deputy Research and Affairs of Bushehr University of Medical
Science with grant number 461 and was approved by the Ethical Committee of the University with reference number IR.BPUMS.REC.1396.117.

2.2. Laboratory Diagnosis. The serum samples were tested for detection of anti-HCV antibodies using an enzymelinked immunosorbent assay (ELISA) (HCV Ab ELISA kit, Dia.Pro, Milan, Italy). The specificity and sensitivity of this kit were $99.5 \%$ and $100 \%$, respectively. All seropositive samples were tested using seminested reverse transcriptasepolymerase chain reaction (RT-PCR) assay as described in our previous study [17]. Briefly, the nucleic acid was extracted from the samples using High Pure Viral Nucleic Acid kit (Roche, Mannheim, Germany) according to the manufacturer's instructions. Following the extraction of viral RNA, the molecular evaluation of HCV infection was performed by nested RT-PCR assay, targeting the $5^{\prime}$ untranslated region ( $\left.5^{\prime} \mathrm{UTR}\right)$ and core of the $\mathrm{HCV}$ genome and sequencing. The extracted HCV RNA was reverse transcribed into cDNA using the SuperScript III cDNA synthesis kit (Invitrogen, Carlsbad, CA, USA). The cDNA was amplified by seminested PCR using outer primers (forward primer (-268 to -251): AGCGTCTAGCCATGGCGT; reverse primer $(+410$ to +391$)$ : ATGTACCCCATGAGGTCGGC) and inner primers (forward primer ( -268 to -251$)$ : AGCG TCTAGCCATGGCGT; reverse primer $(+383$ to +364$)$ : CACGTTAGGGTATCGATGAC). The $680 \mathrm{bp}$ and $580 \mathrm{bp}$ length fragments of the HCV genome from the 5 'UTR through core were amplified by these sets of seminested primers. The amplicons were sequenced to determine HCV genotypes.

2.3. Statistical Analysis. Data were analyzed by using SPSS 17 package program (SPSS Inc., Chicago, IL, USA) and were compared by Student's $t$-test and chi-square test or Fisher's exact test, and $p$ values $<0.05$ were considered statistically significant. Logistic regression analysis was used to determine the risk factors of $\mathrm{HCV}$ infection among pregnant women, and the odds ratio with $95 \%$ confidence intervals was calculated.

\section{Results}

Serum samples were obtained from 1425 pregnant women, including 616 participants from Bushehr city, 440 participants from Borazjan city, 207 participants from Ahram city, 122 participants from Jam city, and 40 participants from Khormuj city, with ages ranging from 14 to 46 years $(28.1 \pm 5.99)$. Of these, $108(7.6 \%)$ participants were pregnant women less than 20 years old, 283 (19.9\%) were 2024 years old, 503 (35.3\%) were 25-29 years old, 293 (20.6\%) were $30-34$ years old, 192 (13.5\%) were $35-39$ years old, and 46 (3.2\%) were over 39 years old. Of 1425 pregnant women, 19 women $(1.33 \%$, 95\% CI: 0.85\%-2.07\%) were positive for anti-HCV antibodies. The highest rate of anti-HCV seroprevalence was observed in the age group $>39$ years $(2.2 \%)$ followed by the age group 25-29 years $(2.0 \%)$, whereas the lowest anti-HCV seropositivity was found in the age group $<20$ years $(0.9 \%)$ and the age group $20-24$ 
years did not show anti-HCV seropositivity. Anti-HCVseropositive pregnant women had a higher mean age $(29.37 \pm 5.64)$ compared to anti-HCV-seronegative pregnant women $(28.09 \pm 5.6)$, while this difference was not statistically significant $(P=0.35)$. Of the 19 anti-HCVseropositive pregnant women, 17 women had normal levels (up to $32 \mathrm{U} / \mathrm{L}$ ) of alanine transaminase (ALT) and aspartate transaminase (AST). Two anti-HCV-seropositive women had elevated levels of ALT and AST; one of these cases was viremic; this case was also positive for hepatitis B surface antigen (HBsAg) (ALT: 76 U/L and AST: $60 \mathrm{U} / \mathrm{L}$ ). The other case was positive for anti-HCV antibodies but negative for $\mathrm{HCV}$ viremia (ALT: $45 \mathrm{U} / \mathrm{L}$ and AST: $38 \mathrm{U} / \mathrm{L}$ ). Besides, all of the anti-HCV-seropositive samples were negative for HIV.

Regarding ethnicity and place of residency, Arab (1.5\%) and Fars (1.4\%) pregnant women and those residents of Khormuj city $(7.5 \%)$ had the highest anti-HCV seropositivity, while residents of Ahram city (1.0\%) and Afgan and Turk women showed the lowest rate of anti-HCV seroprevalence. The majority of anti-HCV-seropositive women were in the third trimester of pregnancy, educated, and had a history of blood transfusion, abortion, surgery, or dentistry. Nevertheless, anti-HCV seroprevalence among pregnant women was not statistically associated with the number of pregnancies, stage of gestation, age, ethnicity, level of education, time of sampling, history of abortion, blood transfusion, surgery, and dentistry. In contrast, anti-HCV seropositivity was associated with the place of residency, so that residents of Khormuj city had significantly higher anti-HCV seroprevalence compared to the residents of other cities (OR: 7.05; 95\% CI: 1.75-28.39; $P=0.006$ ).

According to the molecular evaluation, 9 of $19 \mathrm{HCV}$ seropositive samples $(47.37 \%)$ had HCV viremia with genotype 3 a. So, 4 samples were found to be positive in the first round of PCR (Figure 1) and 5 samples were positive in the second round of PCR (Figure 2). Regarding sociodemographic characteristics and qualitative variables, no statistical difference was found between anti-HCV-positive samples with viremia and anti-HCV-positive samples without viremia. Overall, the prevalence of $\mathrm{HCV}$ viremia among pregnant women was $0.63 \%$ (95\% CI: $0.33 \%-1.19 \%)$. The mean age of pregnant women with $\mathrm{HCV}$ viremia $(31.0 \pm 3.71)$ was higher than that of HCV RNA-negative pregnant women $(28.09 \pm 5.99)$, but this difference was statistically insignificant $(P=0.146)$. Except for the place of residency, almost no risk factor was found for $\mathrm{HCV}$ viremia among pregnant women. HCV viremia was significantly higher among pregnant women of Khormuj city (5\%) than those of the other cities (1.65\%) (OR: 10.75; 95\% CI: 1.74-66.3; $P$ $=0.010)$. The prevalence of anti-HCV antibodies and $\mathrm{HCV}$ viremia among pregnant women grouped according to sociodemographic characteristics and qualitative variables is presented in Tables 1 and 2 .

\section{Discussion}

HCV infection, with a global prevalence rate of $2.8 \%$ and more than 350000 deaths annually, is considered to be the

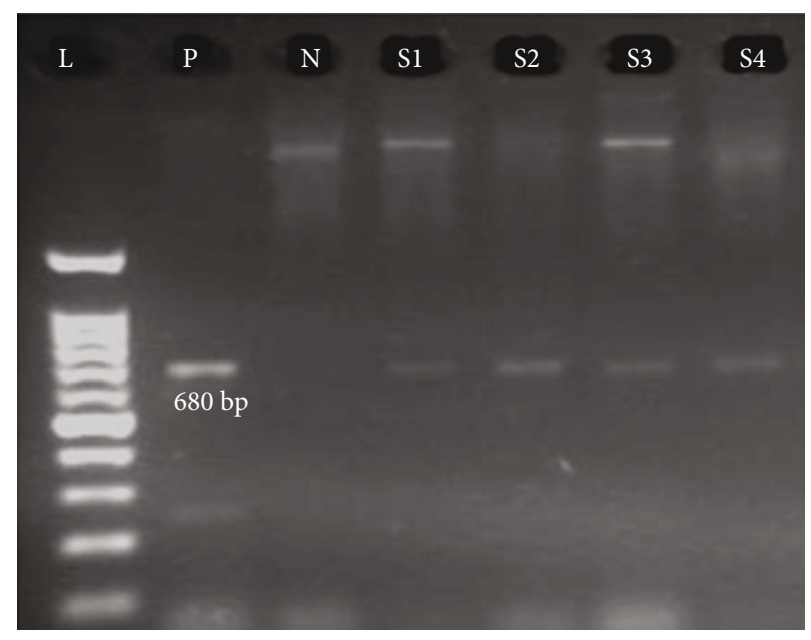

FIgURE 1: The first round of RT-PCR amplification of HCV RNA extracted from samples of pregnant women. L: $100 \mathrm{bp}$ DNA ladder; P: positive control; N: negative control; S1-S4: amplified product $(680 \mathrm{bp})$ on $2 \%$ agarose gel electrophoresis.

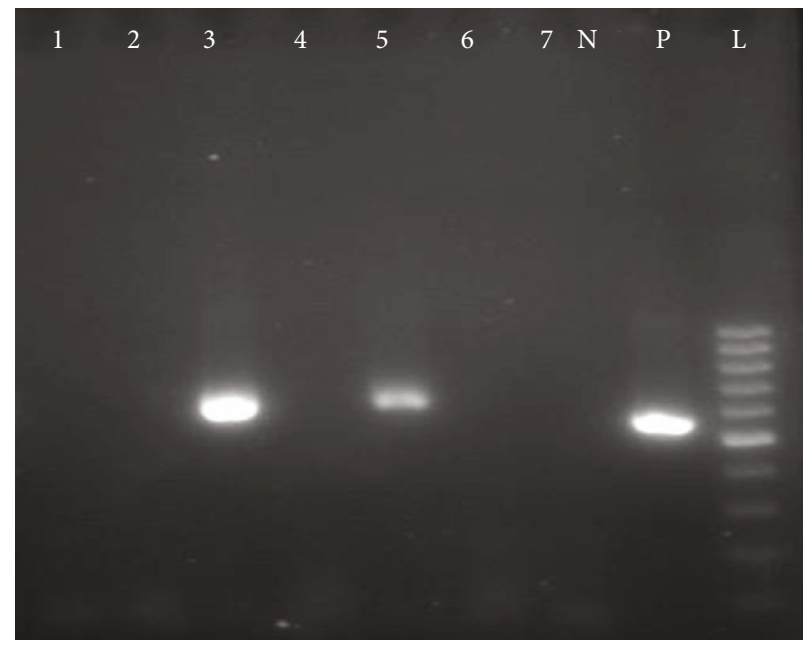

FIgURe 2: The second set of RT-PCR amplification of negative PCR products from first-round PCR. L: $100 \mathrm{bp}$ DNA ladder; P: positive control; N: negative control; 3 and 5: amplified product (580 bp) on $2 \%$ agarose gel electrophoresis.

major causative agent of viral hepatitis-related mortality [1]. Nevertheless, the epidemiological pattern of HCV infection among pregnant women, one of the most vulnerable population groups, remains unknown in most parts of the world. Besides, no report is available on molecular identification and risk factors of $\mathrm{HCV}$ infection among pregnant women in the northern shores of the Persian Gulf, Iran. Therefore, in this survey, we investigated the prevalence and genotypic pattern of HCV infection among pregnant women in this territory and found the HCV prevalence of $1.33 \%$ for anti-HCV antibodies and $0.63 \%$ for $\mathrm{HCV}$ viremia with genotype $3 \mathrm{a}$.

The HCV seroprevalence of $1.33 \%$ observed in the pregnant women is considerably higher than the HCV prevalence of $0.1 \%$ identified in the blood donors of this 
TABle 1: Prevalence of anti-HCV antibodies according to sociodemographic characteristics and qualitative variables among pregnant women in the south of Iran.

\begin{tabular}{|c|c|c|c|c|c|}
\hline & $\begin{array}{l}\text { No. of all participants } \\
(\%): 1425(100 \%)\end{array}$ & $\begin{array}{l}\text { No. of HCV Ab-negative subjects } \\
(\%): 1406(98.67 \%)\end{array}$ & $\begin{array}{l}\text { No. of HCV Ab-positive } \\
\text { subjects (\%): } 19(1.33 \%)\end{array}$ & $\begin{array}{l}\text { Adjusted OR } \\
(95 \% \mathrm{CI})\end{array}$ & $\begin{array}{c}P \\
\text { value }\end{array}$ \\
\hline \multicolumn{6}{|l|}{ Age groups (years) } \\
\hline$<20$ & $108(7.6 \%)$ & 107 (99.1\%) & $1(0.9 \%)$ & 1.0 & \\
\hline $20-24$ & $283(19.9 \%)$ & $283(100.0 \%)$ & $0(0.0 \%)$ & $2.17(0.27-17.13)$ & 0.994 \\
\hline $25-29$ & $503(35.3 \%)$ & $493(98.0 \%)$ & $10(2.0 \%)$ & $1.48(0.16-13.4)$ & 0.462 \\
\hline $30-34$ & $293(20.6 \%)$ & $289(98.6 \%)$ & $4(1.4 \%)$ & $1.69(0.17-16.53)$ & 0.727 \\
\hline $35-39$ & $192(13.5 \%)$ & $189(98.4 \%)$ & $3(1.6 \%)$ & $2.38(0.15-38.85)$ & 0.648 \\
\hline$>39$ & $46(3.2 \%)$ & $45(97.8 \%)$ & $1(2.2 \%)$ & $2.17(0.27-17.13)$ & 0.543 \\
\hline \multicolumn{6}{|l|}{ Place of residence (city) } \\
\hline Bushehr & $616(43.2 \%)$ & $609(98.9 \%)$ & $7(1.1 \%)$ & 1.0 & \\
\hline Borazjan & $440(30.9 \%)$ & $435(98.9 \%)$ & $5(1.1 \%)$ & $1.0(0.32-3.17)$ & 1.000 \\
\hline Ahram & $207(14.50 \%)$ & $205(99.1 \%)$ & $2(1.0 \%)$ & $0.85(0.17-4.12)$ & 0.839 \\
\hline Jam & $122(8.6 \%)$ & $120(98.4 \%)$ & $2(1.6 \%)$ & $1.45(0.29-7.06)$ & 0.646 \\
\hline Khormuj & $40(2.8 \%)$ & $37(92.5 \%)$ & $3(7.5 \%)$ & $7.05(1.75-28.39)$ & 0.006 \\
\hline \multicolumn{6}{|l|}{ Ethnicity } \\
\hline Fars & $1283(90.0 \%)$ & $1265(98.6 \%)$ & $18(1.4 \%)$ & 1.0 & \\
\hline Arab & $68(4.8 \%)$ & $67(98.5 \%)$ & $1(1.5 \%)$ & $1.05(0.14-7.98)$ & 0.963 \\
\hline Afghan & $62(4.4 \%)$ & $62(100.0 \%)$ & $0(0.0 \%)$ & 0.00 & 0.997 \\
\hline Turk & $12(0.8 \%)$ & $12(100.0 \%)$ & $0(0.0 \%)$ & 0.00 & 0.999 \\
\hline \multicolumn{6}{|l|}{ Stage of gestation } \\
\hline First trimester & $256(18.0 \%)$ & $256(100.0 \%)$ & $0(0.0 \%)$ & 1.0 & \\
\hline Second trimester & $194(13.6 \%)$ & $193(99.5 \%)$ & $1(0.5 \%)$ & 0.00 & 0.995 \\
\hline Third trimester & $975(68.4 \%)$ & $957(98.2 \%)$ & $18(1.8 \%)$ & $0.275(0.04-2.08)$ & 0.211 \\
\hline \multicolumn{6}{|l|}{ Number of pregnancies } \\
\hline One pregnancy & $440(30.9 \%)$ & $434(98.6 \%)$ & $6(1.4 \%)$ & 1.0 & \\
\hline Two pregnancies & $453(31.8)$ & $444(98.0 \%)$ & $9(2.0 \%)$ & $1.466(0.51-4.15)$ & 0.471 \\
\hline Three pregnancies & $332(23.3)$ & $330(99.4 \%)$ & $2(0.6 \%)$ & $0.438(0.09-2.19)$ & 0.314 \\
\hline Four pregnancies & $134(9.4 \%)$ & $132(98.5 \%)$ & $2(1.5 \%)$ & $1.096(0.22-5.49)$ & 0.911 \\
\hline $\begin{array}{l}\text { More than four } \\
\text { pregnancies }\end{array}$ & $66(4.6 \%)$ & $66(100.0 \%)$ & $0(0.0 \%)$ & 0.00 & 0.997 \\
\hline \multicolumn{6}{|l|}{ History of abortion } \\
\hline No & $934(65.5 \%)$ & $921(98.6 \%)$ & $13(1.4 \%)$ & 1.0 & \\
\hline Yes & $231(16.2 \%)$ & $227(98.3 \%)$ & $4(1.7 \%)$ & $1.248(0.40-3.86)$ & 0.700 \\
\hline Unknown & $260(18.2 \%)$ & $258(99.2 \%)$ & $2(0.8 \%)$ & $0.549(0.12-2.45)$ & 0.432 \\
\hline \multicolumn{6}{|l|}{ Education } \\
\hline Upper diploma & $366(25.7 \%)$ & $360(98.4 \%)$ & $6(1.6 \%)$ & 1.0 & \\
\hline Diploma & $677(47.5 \%)$ & $666(98.4 \%)$ & $11(1.6 \%)$ & $0.99(0.36-2.70)$ & 0.986 \\
\hline Under diploma & $340(23.9 \%)$ & $338(99.4 \%)$ & $2(0.6 \%)$ & $0.35(0.07-1.77)$ & 0.207 \\
\hline Uneducated & $42(2.9 \%)$ & $42(100.0 \%)$ & $0(0.0 \%)$ & 0.00 & 0.998 \\
\hline \multicolumn{6}{|l|}{ Year } \\
\hline 2018 & 797 (55.9\%) & $792(99.4 \%)$ & $5(0.6 \%)$ & 1.0 & \\
\hline 2019 & $628(44.1 \%)$ & $614(97.8 \%)$ & $14(2.2 \%)$ & $3.61(1.29-10.08)$ & 0.014 \\
\hline \multicolumn{6}{|l|}{ Month } \\
\hline Oct & $113(7.9 \%)$ & $112(99.1 \%)$ & $1(0.9 \%)$ & 1.0 & \\
\hline Nov & $102(7.2 \%)$ & $102(100.0 \%)$ & $0(0.0 \%)$ & 0.00 & 0.997 \\
\hline Dec & $112(7.9 \%)$ & $111(99.1 \%)$ & $1(0.9 \%)$ & $1.01(0.06-16.33)$ & 0.995 \\
\hline Jan & $108(7.6 \%)$ & $105(97.2 \%)$ & $3(2.8 \%)$ & $3.20(0.33-31.25)$ & 0.317 \\
\hline Feb & $291(20.4 \%)$ & $290(99.7 \%)$ & $1(0.3 \%)$ & $0.39(0.02-6.23)$ & 0.502 \\
\hline
\end{tabular}


TABLE 1: Continued.

\begin{tabular}{|c|c|c|c|c|c|}
\hline & $\begin{array}{l}\text { No. of all participants } \\
\text { (\%): } 1425(100 \%)\end{array}$ & $\begin{array}{l}\text { No. of HCV Ab-negative subjects } \\
\text { (\%): } 1406(98.67 \%)\end{array}$ & $\begin{array}{l}\text { No. of HCV Ab-positive } \\
\text { subjects (\%): } 19(1.33 \%)\end{array}$ & $\begin{array}{l}\text { Adjusted OR } \\
\quad(95 \% \mathrm{CI})\end{array}$ & $\begin{array}{c}P \\
\text { value }\end{array}$ \\
\hline Mar & $248(17.4 \%)$ & $246(99.2 \%)$ & $2(0.8 \%)$ & $0.91(0.08-10.15)$ & 0.939 \\
\hline Apr & $131(9.2 \%)$ & $128(97.7 \%)$ & $3(2.3 \%)$ & $2.63(0.27-25.59)$ & 0.406 \\
\hline May & $168(11.8 \%)$ & $162(96.4 \%)$ & $6(3.6 \%)$ & $4.15(0.49-34.93)$ & 0.191 \\
\hline June & $123(8.6 \%)$ & $122(99.2 \%)$ & $1(0.8 \%)$ & $0.92(0.06-14.85)$ & 0.952 \\
\hline July & $29(2.0 \%)$ & $28(96.6 \%)$ & $1(3.4 \%)$ & $4.00(0.24-65.95)$ & 0.332 \\
\hline \multicolumn{6}{|l|}{ Smoking } \\
\hline No & $836(58.7 \%)$ & $821(98.2 \%)$ & $15(1.8 \%)$ & 1.0 & \\
\hline Yes & $62(4.4 \%)$ & $61(98.4 \%)$ & $1(1.6 \%)$ & $0.90(0.12-6.91)$ & 0.917 \\
\hline Unknown & $527(37.0 \%)$ & $524(99.4 \%)$ & $3(0.6 \%)$ & $0.31(0.09-1.09)$ & 0.068 \\
\hline \multicolumn{6}{|c|}{$\begin{array}{l}\text { History of blood } \\
\text { injection }\end{array}$} \\
\hline No & $892(62.6 \%)$ & $877(98.3 \%)$ & $15(1.7 \%)$ & 1.0 & \\
\hline Yes & $18(1.3 \%)$ & $17(94.4 \%)$ & $1(5.6 \%)$ & $3.44(0.43-27.54)$ & 0.245 \\
\hline Unknown & $515(36.1 \%)$ & $512(99.4 \%)$ & $3(0.6 \%)$ & $0.34(0.10-1.19)$ & 0.092 \\
\hline \multicolumn{6}{|c|}{ History of operation } \\
\hline No & $692(48.6 \%)$ & $683(98.7 \%)$ & $9(1.3 \%)$ & 1.0 & \\
\hline Yes & $218(15.3 \%)$ & $211(96.8 \%)$ & $7(3.2 \%)$ & $2.52(0.93-6.84)$ & 0.070 \\
\hline Unknown & $515(36.1 \%)$ & $512(99.4 \%)$ & $3(0.6 \%)$ & $0.45(0.12-1.65)$ & 0.226 \\
\hline \multicolumn{6}{|c|}{ History of tattoo } \\
\hline No & $786(55.2 \%)$ & $771(98.1 \%)$ & $15(1.9 \%)$ & 1.0 & \\
\hline Yes & $124(8.7 \%)$ & $123(99.2 \%)$ & $1(0.8 \%)$ & $0.42(0.05-3.19)$ & 0.400 \\
\hline Unknown & $515(36.1 \%)$ & $512(99.4 \%)$ & $3(0.6 \%)$ & $0.30(0.09-1.05)$ & 0.059 \\
\hline \multicolumn{6}{|c|}{ History of dentistry } \\
\hline No & $504(35.4 \%)$ & $497(98.6 \%)$ & $7(1.4 \%)$ & 1.0 & \\
\hline Yes & $406(28.5 \%)$ & $397(97.8 \%)$ & $9(2.2 \%)$ & $1.61(0.59-4.36)$ & 0.349 \\
\hline Unknown & $515(36.1 \%)$ & $512(99.4 \%)$ & $3(0.6 \%)$ & $0.42(0.11-1.62)$ & 0.206 \\
\hline \multicolumn{6}{|c|}{$\begin{array}{l}\text { History of } \mathrm{HBV} \\
\text { vaccination }\end{array}$} \\
\hline No & $314(22.0 \%)$ & $305(97.1 \%)$ & $9(2.9 \%)$ & 1.0 & \\
\hline Yes & $314(22.0 \%)$ & $309(98.4 \%)$ & $5(1.6 \%)$ & $0.55(0.18-1.65)$ & 0.286 \\
\hline Unknown & 797 (55.9\%) & $792(99.4 \%)$ & $5(0.6 \%)$ & $0.21(0.07-0.64)$ & 0.006 \\
\hline
\end{tabular}

territory [18]. Besides, the HCV seroprevalence reported in this study is higher than those reported among the blood donors $(0.5 \%)$ and the general population $(0.6 \%)$ of Iran $[15,16]$. Therefore, the pregnant population of this territory should be considered as the at-risk population. Moreover, all the $\mathrm{HCV}$-infected pregnant women were unaware of their infection, which may be indicative of the asymptomatic nature of chronic HCV infection. Screening for HCV infection can result in an increase in the identification of infected but asymptomatic pregnant women and neonates born at risk. Therefore, detection of $\mathrm{HCV}$ infection should be included in the screening program of pregnant women to prevent those procedures that can increase the fetus' exposure to HCV and improve clinical management of infants born to infected mothers. Moreover, routine screening of women of childbearing age for $\mathrm{HCV}$ infection before pregnancy and antiviral treatment of $\mathrm{HCV}$-infected patients can mitigate the risk of mother-to-child transmission and complications of HCV infection during pregnancy such as cholestasis and preterm birth [19, 20]. The prompt diagnosis and proper treatment of infected individuals as well as timely interventions and public education improve prevention and management strategies and, consequently, reduce the rate of infection in the community [1].

The seroprevalence of $1.33 \%$ for anti HCV antibodies reported in this study is higher than those reported among pregnant women in some parts of Iran, $0.98 \%$ in Malekan (northwest of Iran) [21] and $0.2 \%$ in Lorestan (west of Iran) [22]. The anti-HCV seroprevalence reported in the present study is also higher than those reported among pregnant women in Sweden (0.6\%) [23], Central Sudan (0.6\%) [24], Tanzania (0.3\%) [25], Central Brazil (0.22\%) [26], Saudi Arabia (0.07\%) [27], Eastern Turkey (0.06\%) [28], and Kurdistan Region of Iraq (0.04\%) [29] but slightly lower than those of Ghana (7.7\%) [30], Cameroon (1.9\%) [31], Northeast Italy (1.9\%) [32], Ethiopia (1.8\%) [33], India (1.7\%) [34], Egypt (1.7\%) [35], Pakistan (1.42\%) [36], and Nigeria $(1.39 \%)$ [37]. These variations in the prevalence of $\mathrm{HCV}$ 
TABLE 2: Prevalence of HCV viremia according to sociodemographic characteristics and qualitative variables among pregnant women in the south of Iran.

$\begin{array}{cccc} & \text { No. of HCV } & \text { No. of HCV } & \\ \text { No. of all participants } & \text { RNA-positive } & \text { Adjusted OR (95\% CI) } P \text { value } \\ \text { (\%): } 1425(100 \%) & (\%): 1416(98.67 \%) & \begin{array}{c}\text { subjects (\%):9 } \\ (0.63 \%)\end{array} & \\ & & \end{array}$

\begin{tabular}{|c|c|c|c|c|c|}
\hline \multicolumn{6}{|l|}{ Age groups (years) } \\
\hline$<20$ & $108(7.6 \%)$ & $108(100.0 \%)$ & $0(0.0 \%)$ & 1.0 & \\
\hline $20-24$ & $283(19.9 \%)$ & $283(100.0 \%)$ & $0(0.0 \%)$ & 0.00 & 1.000 \\
\hline $25-29$ & $503(35.3 \%)$ & $499(99.2 \%)$ & $4(0.8 \%)$ & 0.00 & 0.995 \\
\hline $30-34$ & $293(20.6 \%)$ & $290(98.98 \%)$ & $3(1.02 \%)$ & $0.77(0.17-3.49)$ & 0.740 \\
\hline $35-39$ & $192(13.5 \%)$ & $190(98.95 \%)$ & $2(1.05 \%)$ & $0.98(0.16-5.94)$ & 0.985 \\
\hline$>39$ & $46(3.2 \%)$ & $46(100.0 \%)$ & $0(0.0 \%)$ & 0.00 & 0.998 \\
\hline \multicolumn{6}{|l|}{ Place of residence (city) } \\
\hline Bushehr & $616(43.2 \%)$ & $613(99.01 \%)$ & $3(0.49 \%)$ & 1.0 & \\
\hline Borazjan & $440(30.9 \%)$ & $437(98.9 \%)$ & $3(0.68 \%)$ & $1.4(0.28-6.98)$ & 0.679 \\
\hline Ahram & $207(14.50 \%)$ & $206(99.1 \%)$ & $1(0.48 \%)$ & $0.99(0.1-9.58)$ & 0.994 \\
\hline Jam & $122(8.6 \%)$ & $122(98.4 \%)$ & $0(0.0 \%)$ & 0.00 & 0.997 \\
\hline Khormuj & $40(2.8 \%)$ & $38(92.5 \%)$ & $2(5 \%)$ & $10.75(1.74-66.3)$ & 0.010 \\
\hline \multicolumn{6}{|l|}{ Ethnicity } \\
\hline Fars & $1283(90.0 \%)$ & $1275(99.38 \%)$ & $8(0.62 \%)$ & 1.0 & \\
\hline Arab & $68(4.8 \%)$ & $67(98.53 \%)$ & $1(1.47 \%)$ & $2.38(0.29-19.29)$ & 0.417 \\
\hline Afghan & $62(4.4 \%)$ & $62(100.0 \%)$ & $0(0.0 \%)$ & 0.00 & 0.997 \\
\hline Turk & $12(0.8 \%)$ & $12(100.0 \%)$ & $0(0.0 \%)$ & 0.00 & 0.999 \\
\hline \multicolumn{6}{|l|}{ Stage of gestation } \\
\hline First trimester & $256(18.0 \%)$ & $256(100.0 \%)$ & $0(0.0 \%)$ & 1.0 & \\
\hline Second trimester & $194(13.6 \%)$ & $193(99.49 \%)$ & $1(0.51 \%)$ & 0.00 & 0.995 \\
\hline Third trimester & $975(68.4 \%)$ & $967(99.18 \%)$ & $8(0.82 \%)$ & 0.00 & 0.995 \\
\hline \multicolumn{6}{|l|}{ Number of pregnancies } \\
\hline One pregnancy & $440(30.9 \%)$ & $438(99.55 \%)$ & $2(0.45 \%)$ & 1.0 & \\
\hline Two and three pregnancies & $785(55.09 \%)$ & $780(99.12 \%)$ & $5(0.64 \%)$ & $1.40(0.27-7.28)$ & 0.686 \\
\hline $\begin{array}{l}\text { More than three } \\
\text { pregnancies }\end{array}$ & $200(14.04 \%)$ & $198(100.0 \%)$ & $2(1.0 \%)$ & $2.12(0.31-15.82)$ & 0.429 \\
\hline \multicolumn{6}{|l|}{ History of abortion } \\
\hline No & $934(65.5 \%)$ & $930(99.57 \%)$ & $4(0.43 \%)$ & 1.0 & \\
\hline Yes & $231(16.2 \%)$ & $228(98.7 \%)$ & $3(1.3 \%)$ & $3.06(0.68-13.76)$ & 0.145 \\
\hline Unknown & $260(18.2 \%)$ & $258(99.23 \%)$ & $2(0.77 \%)$ & $1.80(0.33-9.89)$ & 0.498 \\
\hline \multicolumn{6}{|l|}{ Education } \\
\hline Upper diploma & $366(25.7 \%)$ & $363(99.18 \%)$ & $3(0.82 \%)$ & 1.0 & \\
\hline Diploma & $677(47.5 \%)$ & $671(99.11 \%)$ & $6(0.89 \%)$ & $1.08(0.27-4.35)$ & 0.912 \\
\hline Under diploma & $340(23.9 \%)$ & $340(100.0 \%)$ & $0(0.0 \%)$ & 0.00 & 0.994 \\
\hline Uneducated & $42(2.9 \%)$ & $42(100.0 \%)$ & $0(0.0 \%)$ & 0.00 & 0.998 \\
\hline \multicolumn{6}{|l|}{ Year } \\
\hline 2018 & 797 (55.9\%) & $794(99.62 \%)$ & $3(0.38 \%)$ & 1.0 & \\
\hline 2019 & $628(44.1 \%)$ & $622(99.04 \%)$ & $6(0.96 \%)$ & $2.55(0.64-10.25)$ & 0.186 \\
\hline \multicolumn{6}{|l|}{ Month } \\
\hline Oct & $113(7.9 \%)$ & $113(100.0 \%)$ & $0(0.0 \%)$ & 1.0 & \\
\hline Nov & $102(7.2 \%)$ & $102(100.0 \%)$ & $0(0.0 \%)$ & 1.00 & 1.000 \\
\hline Dec & $112(7.9 \%)$ & $111(0.11 \%)$ & $1(0.89 \%)$ & 0.00 & 0.997 \\
\hline Jan & $108(7.6 \%)$ & 107 (99.07\%) & $1(0.93 \%)$ & $0.96(0.06-15.61)$ & 0.979 \\
\hline Feb & $291(20.4 \%)$ & $290(99.66 \%)$ & $1(0.34 \%)$ & $2.71(0.17-43.72)$ & 0.482 \\
\hline
\end{tabular}


TABLE 2: Continued.

\begin{tabular}{|c|c|c|c|c|c|}
\hline & $\begin{array}{l}\text { No. of all participants } \\
\text { (\%): } 1425(100 \%)\end{array}$ & $\begin{array}{c}\text { No. of HCV } \\
\text { RNA-negative subjects } \\
(\%): 1416(98.67 \%)\end{array}$ & $\begin{array}{c}\text { No. of HCV } \\
\text { RNA-positive } \\
\text { subjects }(\%): 9 \\
(0.63 \%)\end{array}$ & Adjusted OR (95\% CI) & $P$ value \\
\hline Mar & $248(17.4 \%)$ & $247(99.6 \%)$ & $1(0.4 \%)$ & $0.85(0.05-13.69)$ & 0.910 \\
\hline Apr & $131(9.2 \%)$ & $130(99.31 \%)$ & $1(0.76 \%)$ & $0.53(0.03-8.48)$ & 0.651 \\
\hline May & $168(11.8 \%)$ & $165(98.21 \%)$ & $3(1.79 \%)$ & $0.42(0.04-4.11)$ & 0.459 \\
\hline June & $123(8.6 \%)$ & $122(99.19 \%)$ & $1(0.81 \%)$ & $2.22(0.23-21.58)$ & 0.493 \\
\hline July & $29(2.0 \%)$ & $29(100.0 \%)$ & $0(0.0 \%)$ & 1.00 & 0.998 \\
\hline \multicolumn{6}{|l|}{ Smoking } \\
\hline No & $836(58.7 \%)$ & $829(99.16 \%)$ & $7(0.84 \%)$ & 1.0 & \\
\hline Yes & $62(4.4 \%)$ & $62(100.0 \%)$ & $0(0.0 \%)$ & 0.00 & 0.997 \\
\hline Unknown & $527(37.0 \%)$ & $525(99.62 \%)$ & $2(0.38 \%)$ & $0.45(0.09-2.18)$ & 0.322 \\
\hline \multicolumn{6}{|c|}{ History of blood injection } \\
\hline No & $892(62.6 \%)$ & $885(98.3 \%)$ & $7(0.79 \%)$ & 1.0 & \\
\hline Yes & $18(1.3 \%)$ & $18((100.0 \%)$ & $0(0.0 \%)$ & 0.00 & 0.999 \\
\hline Unknown & $515(36.1 \%)$ & $513(99.62 \%)$ & $2(0.38 \%)$ & $0.49(0.10-2.38)$ & 0.379 \\
\hline \multicolumn{6}{|c|}{ History of operation } \\
\hline No & $692(48.6 \%)$ & $688(99.42 \%)$ & $4(0.58 \%)$ & 1.0 & \\
\hline Yes & $218(15.3 \%)$ & $215(98.62 \%)$ & $3(1.38 \%)$ & $2.40(0.53-10.81)$ & 0.254 \\
\hline Unknown & $515(36.1 \%)$ & $513(99.61 \%)$ & $2(0.39 \%)$ & $0.67(0.12-3.67)$ & 0.645 \\
\hline \multicolumn{6}{|c|}{ History of tattoo } \\
\hline No & $786(55.2 \%)$ & $779(99.11 \%)$ & $7(0.89 \%)$ & 1.0 & \\
\hline Yes & $124(8.7 \%)$ & $124(100.0 \%)$ & $0(0.0 \%)$ & 0.00 & 0.996 \\
\hline Unknown & $515(36.1 \%)$ & $513(99.61 \%)$ & $2(0.39 \%)$ & $0.43(0.09-2.10)$ & 0.299 \\
\hline \multicolumn{6}{|c|}{ History of dentistry } \\
\hline No & $504(35.4 \%)$ & $501(99.4 \%)$ & $3(0.6 \%)$ & 1.0 & \\
\hline Yes & $406(28.5 \%)$ & $402(99.01 \%)$ & $4(0.99 \%)$ & $1.66(0.37-7.47)$ & 0.508 \\
\hline Unknown & $515(36.1 \%)$ & $513(99.61 \%)$ & $2(0.39 \%)$ & $0.65(0.11-3.91)$ & 0.639 \\
\hline \multicolumn{6}{|c|}{ History of $\mathrm{HBV}$ vaccination } \\
\hline No & $314(22.0 \%)$ & $310(98.73 \%)$ & $4(1.27 \%)$ & 1.0 & \\
\hline Yes & $314(22.0 \%)$ & $312(99.36 \%)$ & $2(0.64 \%)$ & $0.50(0.09-2.73)$ & 0.421 \\
\hline Unknown & $797(55.9 \%)$ & $794(99.62 \%)$ & $3(0.38 \%)$ & $0.30(0.06-1.32)$ & 0.109 \\
\hline
\end{tabular}

infection might be due to differences in HCV epidemiological patterns, risk factors, the routes of transmission, and general health status in different regions of the world. However, these variations can be explained by differences in sociodemographic characteristics of the study population, sample size, study period, time of sampling, and specificity and sensitivity of diagnostic methods in different studies.

In this study, the highest rate of anti-HCV seroprevalence was observed in the age group $>39$ years followed by the age group 25-29 years. In our previous study among the blood donors of this territory, the highest rate of anti$\mathrm{HCV}$ seroprevalence was reported in the age group 31 to 40 years followed by the age group 20 to 30 years [18]. Previous studies from the west and the northwest of Iran showed the highest rates of anti-HCV seropositivity among pregnant women aged $<20$ years and 25 to 29 years, respectively $[21,22]$. Besides, in this study, the mean age of HCVseropositive pregnant women was higher than that of $\mathrm{HCV}$ seronegative pregnant women. This is in accordance with the age distribution of HCV in Southwest Ethiopia [38] and Egypt [39], where hepatitis $C$ is more prevalent among older pregnant women. The high prevalence of HCV infection among older pregnant women is a cause for concern. Considering the complications of chronic HCV infection, preventive strategies, appropriate precautions, and training programs are recommended to reduce the incidence and adverse effects of $\mathrm{HCV}$ infection in the pregnant population.

According to the result of the present study, HCV seropositivity among the pregnant women was not statistically associated with the number of pregnancies, stage of gestation, age, ethnicity, level of education, time of sampling, history of abortion, blood transfusion, surgery, and dentistry, although the majority of $\mathrm{HCV}$-seropositive women were in the third trimester of pregnancy, educated, and had a history of blood transfusion, abortion, surgery, or dentistry. Previous studies from the west and northwest of Iran revealed almost no risk factor for HCV seropositivity among pregnant women $[21,22]$. The same findings have been reported 
in the study of Chibwe et al. [25]. In contrast, some studies from Egypt, Pakistan, and Ghana have reported a significant association between the history of blood transfusion and HCV seropositivity [30, 35, 39, 40]. Previous studies from Egypt showed a significant association between HCV seropositivity and the history of schistosomiasis [35, 39]. Baldo et al. and Bafa and Egata demonstrated that the HCV seroprevalence among pregnant women in Italy and Ethiopia is associated with the history of previous abortion [32, 33]. Ephraim et al. demonstrated that the HCV seroprevalence among pregnant women in Ghana is associated with tattooing and needle sharing [30]. This discrepancy between results in different studies might be due to some differences in risk behavior patterns and the predominant routes of transmission in different regions.

Furthermore, we found a significant association between HCV seropositivity and place of residency, so the residents of Khormuj city had significantly higher HCV seroprevalence compared to the residents of other cities. However, this finding cannot be generalized to the pregnant population of Khormuj city due to the low number of the assessed pregnant women. This higher prevalence might be due to the higher prevalence of $\mathrm{HCV}$ in the general population of this city. Therefore, residents of Khormuj city can be considered as the main at-risk population in the northern shores of the Persian Gulf. However, more studies among different groups in Khormuj city are required to confirm this issue.

Although HCV infection has been observed throughout the year, the prevalence of HCV infection was more prevalent in those samples collected in May (1.79\%). The reason for this observation is not clear. The demand for blood transfusion, elective surgeries, tattooing and piercing for wedding ceremonies, sexual activity, and illicit drug use, which are supposed to be higher in spring, may explain the higher prevalence of HCV infection in May. Overall, the difference in the monthly rate of $\mathrm{HCV}$ infection was statistically insignificant. Research to determine the seasonal or monthly pattern of HCV infection is warranted. Moreover, a significantly higher HCV seroprevalence was reported during $2019(2.2 \%)$ than $2018(0.6 \%)$ among pregnant women (OR: 3.61 ; 95\% CI: $1.29-10.08 ; P=0.014)$. The lurking epidemic of HCV in Iran, which is increasing silently due to an increase in injecting drug use in the society [41], might expose pregnant women to a greater risk of acquiring hepatitis $\mathrm{C}$ in years.

The HCV prevalence of $1.33 \%$ observed in pregnant women is lower than the HCV prevalence of $1.98 \%$ reported in the diabetic population of Southern Iran [17]. The possible reasons for the higher prevalence of HCV infection in diabetic patients can be their older age and also more frequent visits to medical centers or the probable link between diabetes and HCV infection. In addition, 91\% of diabetic patients with positive $\mathrm{HCV}$ antibody tests had HCV viremia [17]. While in the present study, $47.37 \%$ of anti-HCVseropositive samples were positive for HCV RNA. Those anti-HCV-positive samples with a negative HCV RNA test are defined as past HCV infection. In this study, the prevalence of HCV viremia among pregnant women was $0.63 \%$. The prevalence of $\mathrm{HCV}$ viremia observed in this study is higher than the HCV viremia prevalence of $0.4 \%$ reported in the general population of Iran [16] that are shown in supplementary Table 1 .

According to the results of the present study, genotype $3 \mathrm{a}$ is the only genotype found among HCV-infected pregnant women. The same result has been reported in the diabetic population of southern Iran [17]. It seems that HCV genotype $3 \mathrm{a}$ observed in this study follows the predominant genotypic pattern of HCV in this territory. Although genotype $1 \mathrm{a}$ is the most prevalent genotype in Iran, genotype $3 \mathrm{a}$ has been increasing in recent years. Genotype 1a is more common in older people and genotype $3 \mathrm{a}$ in younger people and intravenous drug users. Therefore, injecting drug use is likely to play a significant role in the majority of new infections [41, 42]. However, large-scale epidemiological studies in different geographical locations are required to determine the changes in the distribution pattern of HCV genotypes and to reveal the current common genotypes in different high-risk groups. Moreover, the dose, duration, and type of antiviral therapy can be influenced by the genotypic pattern of HCV infection [42-44].

This study is the first report on the prevalence and the genotypic pattern of $\mathrm{HCV}$ infection among pregnant women in the south of Iran, and consecutive recruitment of participants has increased the generalizability of the results to the pregnant women of this region. However, we were not able to confirm the role of injection drug use as the main route of HCV transmission, since a minority of participants respond to the questions regarding injection drug use by their spouses. As another limitation, we could not determine the possible effects of $\mathrm{HCV}$ infection on pregnancy outcomes due to the cross-sectional design of the research, which prevents the follow-up of the infection status in infants born to infected mothers. Moreover, in this study, nested-PCR or the two-step PCR technique was used, which increases the sensitivity of diagnosing chronic HCV infections with low virus titers. So, 4 samples were found to be positive in the first round of PCR and 5 samples were positive in the second round of PCR. Besides, positive samples were reexamined to ensure the accuracy of the results and the absence of technical errors or accidental contamination.

\section{Conclusion}

This study reports the HCV prevalence of $1.33 \%$ for anti$\mathrm{HCV}$ antibodies and $0.63 \%$ for $\mathrm{HCV}$ viremia with genotype $3 \mathrm{a}$ among pregnant women residents in the northern shores of the Persian Gulf, south of Iran. Given that vertical transmission is possible in women with detectable viremia, therefore, screening of women before pregnancy is recommended to reduce the risk of $\mathrm{HCV}$ infection and its complications during pregnancy. According to the results of the present study, the prevalence of $\mathrm{HCV}$ infection among pregnant women in this territory is not insignificant and may remain undiagnosed over time due to the asymptomatic nature of chronic hepatitis $\mathrm{C}$ infection. Considering the complications of chronic HCV infection, preventive strategies, appropriate precautions, and training programs are also recommended 
to reduce the incidence and adverse effects of HCV infection in the pregnant population.

\section{Data Availability}

All relevant data are within the paper.

\section{Ethical Approval}

This study was approved by the Ethical Committee of Bushehr University of Medical Sciences with reference number IR.BPUMS.REC.1396.117.

\section{Conflicts of Interest}

The authors declared that they do not have anything to disclose regarding conflict of interest with respect to this manuscript.

\section{Authors' Contributions}

Taherkhani R. and Farshadpour F. designed and performed the study. Bakhtiari F. performed the study. Farshadpour F. drafted and edited the manuscript. All authors approved the final draft of the manuscript.

\section{Acknowledgments}

The authors would like to acknowledge grant number 461 supported by the Deputy Research and Affairs of the Bushehr University of Medical Sciences, Bushehr, Iran.

\section{Supplementary Materials}

Prevalence of $\mathrm{HCV}$ viremia among anti-HCV positive pregnant women in Iran. (Supplementary Materials)

\section{References}

[1] R. Taherkhani and F. Farshadpour, "Global elimination of hepatitis $\mathrm{C}$ virus infection: progresses and the remaining challenges," World Journal of Hepatology, vol. 9, no. 33, pp. 12391252, 2017.

[2] S. Mahmoudvand, S. Shokri, R. Taherkhani, and F. Farshadpour, "Hepatitis $C$ virus core protein modulates several signaling pathways involved in hepatocellular carcinoma," World Journal of Gastroenterology, vol. 25, no. 1, pp. 42-58, 2019.

[3] Y. E.-E. Abo-Amer, S. Abd-Elsalam, H. Eldosoky et al., "Declining prevalence of hepatitis $\mathrm{C}$ virus among university students in one of the main governorates in Egypt," Infection and Drug Resistance, vol. 11, pp. 2435-2441, 2018.

[4] G. Abdelmoemen, S. A. Khodeir, S. Abou- Saif, A. Kobtan, and S. Abd-Elsalam, "Prevalence of occult hepatitis $\mathrm{C}$ virus among hemodialysis patients in Tanta university hospitals: a singlecenter study," Environmental Science and Pollution Research International, vol. 25, no. 6, pp. 5459-5464, 2018.

[5] P. A. Tovo, C. Calitri, C. Scolfaro, C. Gabiano, and S. Garazzino, "Vertically acquired hepatitis $\mathrm{C}$ virus infection: correlates of transmission and disease progression," World
Journal of Gastroenterology, vol. 22, no. 4, pp. 1382-1392, 2016.

[6] S. Domínguez-Rodríguez, L. Prieto, C. Fernández McPhee et al., "Perinatal HCV transmission rate in HIV/HCV coinfected women with access to ART in Madrid, Spain," PLoS One, vol. 15, no. 4, article e0230109, 2020.

[7] G. Valladares, A. Chacaltana, and M. H. Sjogren, "The management of HCV-infected pregnant women," Annals of Hepatology, vol. 9, Supplement, pp. 92-97, 2010.

[8] M. G. Mavilia and G. Y. Wu, "Mechanisms and prevention of vertical transmission in chronic viral hepatitis," Journal of Clinical and Translational Hepatology, vol. 5, no. 2, pp. 119129, 2017.

[9] L. Benova, Y. A. Mohamoud, C. Calvert, and L. J. Abu-Raddad, "Vertical transmission of hepatitis C virus: systematic review and meta-analysis," Clinical Infectious Diseases, vol. 59, no. 6, pp. 765-773, 2014.

[10] T. Kushner and N. Reau, "Changing epidemiology, implications, and recommendations for hepatitis $\mathrm{C}$ in women of childbearing age and during pregnancy," Journal of Hepatology, vol. 74, no. 3, pp. 734-741, 2021.

[11] E. B. Cottrell, R. Chou, N. Wasson, B. Rahman, and J. M. Guise, "Reducing risk for mother-to-infant transmission of hepatitis C virus: a systematic review for the U.S. Preventive Services Task Force," Annals of Internal Medicine, vol. 158, no. 2, pp. 109-113, 2013.

[12] C. Y. Yeung, H. C. Lee, W. T. Chan, C. B. Jiang, S. W. Chang, and C. K. Chuang, "Vertical transmission of hepatitis C virus: current knowledge and perspectives," World Journal of Hepatology, vol. 6, no. 9, pp. 643-651, 2014.

[13] J. Murakami, I. Nagata, T. Iitsuka et al., "Risk factors for mother-to-child transmission of hepatitis $\mathrm{C}$ virus: maternal high viral load and fetal exposure in the birth canal," Hepatology Research, vol. 42, no. 7, pp. 648-657, 2012.

[14] M. H. F. El-Shabrawi, N. M. Kamal, E. A. Mogahed, M. A. Elhusseini, and M. F. Aljabri, "Perinatal transmission of hepatitis C virus: an update," Archives of Medical Science, vol. 16, no. 6, pp. 1360-1369, 2020.

[15] M. Khodabandehloo, D. Roshani, and K. Sayehmiri, "Prevalence and trend of hepatitis $\mathrm{C}$ virus infection among blood donors in Iran: a systematic review and meta-analysis," Journal of Research in Medical Sciences: The Official Journal of Isfahan University of Medical Sciences, vol. 18, no. 8, pp. 674-682, 2013.

[16] B. Mirminachi, Z. Mohammadi, S. Merat et al., "Update on the prevalence of hepatitis $\mathrm{C}$ virus infection among Iranian general population: a systematic review and meta-analysis," Hepatitis Monthly, vol. 17, no. 2, 2017.

[17] F. Farshadpour, R. Taherkhani, M. R. Ravanbod, and S. S. Eghbali, "Prevalence and genotype distribution of hepatitis $C$ virus infection among patients with type 2 diabetes mellitus," Medical Principles and Practice, vol. 27, no. 4, pp. 308-316, 2018.

[18] F. Farshadpour, R. Taherkhani, S. Tajbakhsh et al., "Prevalence and trends of transfusion-transmissible viral infections among blood donors in south of Iran: an eleven-year retrospective study," PLoS One, vol. 11, no. 6, article e0157615, 2016.

[19] R. Ragusa, L. S. Corsaro, E. Frazzetto, E. Bertino, M. A. Bellia, and G. Bertino, "Hepatitis $\mathrm{C}$ virus infection in children and pregnant women: an updated review of the literature on screening and treatments," American Journal of Perinatology Reports, vol. 10, no. 1, pp. e121-e127, 2020. 
[20] T. Kushner and N. A. Terrault, "Hepatitis C in pregnancy: a unique opportunity to improve the hepatitis $C$ cascade of care," Hepatology Communications, vol. 3, no. 1, pp. 20-28, 2019.

[21] F. Sahaf, A. Tanomand, H. Montazam, and A. Sany, "Seroprevalence of hepatitis C, hepatitis B and HIV and coinfection among pregnant women: a retrospective study in 2006 at Malekan city, Iran," Journal of Research in Medical Sciences, vol. 1, no. 2, pp. 138-141, 2007.

[22] S. R. Mohebbi, A. Sanati, K. Cheraghipour, M. Rostami Nejad, H. M. Shalmani, and M. R. Zali, "Hepatitis C and hepatitis B virus infection: epidemiology and risk factors in a large cohort of pregnant women in Lorestan, west of Iran," Hepatitis Monthly, vol. 11, no. 9, pp. 736-739, 2011.

[23] C. Millbourn, C. Lybeck, A. Psaros Einberg et al., "Anti-HCV prevalence and risk factor-based screening for hepatitis $\mathrm{C}$ in pregnant women and their partners in Sweden," Infectious Diseases, vol. 52, no. 11, pp. 776-785, 2020.

[24] R. M. Elsheikh, A. A. Daak, M. A. Elsheikh, M. S. Karsany, and I. Adam, "Hepatitis B virus and hepatitis $C$ virus in pregnant Sudanese women," Virology Journal, vol. 4, no. 1, p. 104, 2007.

[25] E. Chibwe, V. Silago, E. Kajoro et al., "Antihepatitis B surface antigen and hepatitis $\mathrm{C}$ antibodies among pregnant women in an urban area of Mwanza city, Tanzania," Journal of Pregnancy, vol. 2019, Article ID 7917894, 5 pages, 2019.

[26] Z. B. Costa, G. C. Machado, M. M. Avelino et al., "Prevalence and risk factors for hepatitis $\mathrm{C}$ and HIV-1 infections among pregnant women in Central Brazil," BMC Infectious Diseases, vol. 9, no. 1, 2009.

[27] H. M. Al-Mandeel, M. Alansary, F. Algawahmed, H. Al-Mojally, K. M. Alfaleh, and L. O. Aldakhil, "Seroprevalence of hepatitis B and C, and human immunodeficiency viruses in Saudi pregnant women and rates of vertical transmission," Kuwait Medical Journal, vol. 47, no. 3, pp. 221-224, 2015.

[28] E. Ç. Tanrıverdi, Z. Özkurt, B. G. Kadıŏlu et al., "Seroprevalence of hepatitis $\mathrm{B}$, hepatitis $\mathrm{C}$, and HIV in pregnant women from eastern Turkey," The Turkish Journal of Gastroenterology, vol. 30, no. 3, pp. 260-265, 2019.

[29] N. R. Hussein, H. A. Sharaf, and S. Mahdi, "The prevalence of hepatitis $\mathrm{C}$ virus infection in pregnant women in Duhok city, Kurdistan Region of Iraq: a brief report," Women's Health Bulletin, vol. 6, no. 2, 2019.

[30] R. Ephraim, I. Donko, S. A. Sakyi, J. Ampong, and H. Agbodjakey, "Seroprevalence and risk factors of hepatitis $\mathrm{B}$ and hepatitis $\mathrm{C}$ infections among pregnant women in the Asante Akim North Municipality of the Ashanti region, Ghana; a cross sectional study," African Health Sciences, vol. 15, no. 3, pp. 709-713, 2015.

[31] R. Njouom, C. Pasquier, A. Ayouba et al., "Hepatitis C virus infection among pregnant women in Yaounde, Cameroon: prevalence, viremia, and genotypes," Journal of Medical Virology, vol. 69, no. 3, pp. 384-390, 2003.

[32] V. Baldo, A. Floreani, T. Menegon, P. Grella, D. M. Paternoster, and R. Trivello, "Hepatitis C virus, hepatitis B virus and human immunodeficiency virus infection in pregnant women in north-East Italy: a seroepidemiological study," European Journal of Epidemiology, vol. 16, no. 1, pp. 87-91, 2000.

[33] T. A. Bafa and A. D. Egata, "Seroepidemiological patterns and predictors of hepatitis $\mathrm{B}, \mathrm{C}$ and HIV viruses among pregnant women attending antenatal care clinic of Atat Hospital, Southern Ethiopia," SAGE Open Medicine, vol. 8, 2020.
[34] G. Jahan, N. Jahan, S. Rungta, and A. Ahmad, "Seroprevalence and risk factors of hepatitis B and C infections among pregnant women," International Journal of Research in Medical Sciences, vol. 8, no. 5, pp. 1718-1723, 2020.

[35] A. abdelkader and S. A. Ibrahim, "Prevalence of hepatitis B and $C$ virus infection among pregnant women in Sharkia Governorate, Egypt," Afro-Egyptian Journal of Infectious and Endemic Diseases, vol. 10, no. 2, pp. 200-206, 2020.

[36] I. Ahmad, "Prevalence of hepatitis B and C viral infection among pregnant women in Peshawar, Pakistan," Hepatitis Monthly, vol. 16, no. 6, 2016.

[37] A. Esan, C. Omisakin, T. Ojo-Bola, M. Owoseni, K. Fasakin, and A. Ogunleye, "Sero-prevalence of hepatitis B and hepatitis C Virue co-infection among pregnant women in Nigeria," American Journal of Biomedical Research, vol. 2, no. 1, pp. 11-15, 2014.

[38] B. D. Taye, T. Kassa, L. Teshager et al., "Prevalence and associated risk factors of hepatitis $\mathrm{B}$ and $\mathrm{C}$ virus infections among mothers in Jimma, South West Ethiopia: a community-based study," Ethiopian Medical Journal, vol. 57, 2019.

[39] S. K. Stoszek, M. Abdel-Hamid, S. Narooz et al., "Prevalence of and risk factors for hepatitis $\mathrm{C}$ in rural pregnant Egyptian women," Transactions of the Royal Society of Tropical Medicine and Hygiene, vol. 100, no. 2, pp. 102-107, 2006.

[40] Z. Afsheen, B. Ahmad, and H. Linfang, "Prevalence of hepatitis $\mathrm{C}$ and associated risk factors among pregnant women of district Nowshera, Khyber Pakhtunkhwa," Advancements in Life Sciences, vol. 5, no. 4, pp. 166-170, 2018.

[41] R. Taherkhani and F. Farshadpour, "Lurking epidemic of hepatitis $\mathrm{C}$ virus infection in Iran: a call to action," World Journal of Hepatology, vol. 9, no. 24, pp. 1040-1042, 2017.

[42] R. Taherkhani and F. Farshadpour, "Epidemiology of hepatitis C virus in Iran," World Journal of Gastroenterology, vol. 21, no. 38, pp. 10790-10810, 2015.

[43] F. Farshadpour, M. Makvandi, A. R. Samarbafzadeh, and M. A. Jalalifar, "Determination of hepatitis $\mathrm{C}$ virus genotypes among blood donors in Ahvaz, Iran," Indian Journal of Medical Microbiology, vol. 28, no. 1, pp. 54-56, 2010.

[44] A. A. Mohamed, N. E. T. R. el-Toukhy, E. M. Said et al., "Hepatitis C virus: efficacy of new DAAs regimens," Infectious Disorders Drug Targets, vol. 20, no. 2, pp. 143-149, 2020. 